\title{
Sex Hormone Receptor Signaling in Bladder Cancer: A Potential Target for Enhancing the Efficacy of Conventional Non-Surgical Therapy
}

\author{
Hiroki Ide ${ }^{1}$ and Hiroshi Miyamoto $2,3,4, *$ (D) \\ 1 Department of Urology, Keio University School of Medicine, Tokyo 160-8582, Japan; h-ide@fc4.so-net.ne.jp \\ 2 Department of Pathology \& Laboratory Medicine, University of Rochester Medical Center, \\ Rochester, NY 14642, USA \\ 3 Department of Urology, University of Rochester Medical Center, Rochester, NY 14642, USA \\ 4 James P. Wilmot Cancer Institute, University of Rochester Medical Center, Rochester, NY 14642, USA \\ * Correspondence: hiroshi_miyamoto@urmc.rochester.edu
}

Citation: Ide, H.; Miyamoto, H. Sex Hormone Receptor Signaling in Bladder Cancer: A Potential Target for Enhancing the Efficacy of Conventional Non-Surgical Therapy. Cells 2021, 10, 1169. https:// doi.org/10.3390/cells10051169

Academic Editor: Alexander E. Kalyuzhny

Received: 20 April 2021

Accepted: 6 May 2021

Published: 11 May 2021

Publisher's Note: MDPI stays neutral with regard to jurisdictional claims in published maps and institutional affiliations.

Copyright: (c) 2021 by the authors. Licensee MDPI, Basel, Switzerland. This article is an open access article distributed under the terms and conditions of the Creative Commons Attribution (CC BY) license (https:// creativecommons.org/licenses/by/ $4.0 /)$.

\begin{abstract}
There have been critical problems in the non-surgical treatment for bladder cancer, especially residence to intravesical pharmacotherapy, including BCG immunotherapy, cisplatin-based chemotherapy, and radiotherapy. Recent preclinical and clinical evidence has suggested a vital role of sex steroid hormone-mediated signaling in the progression of urothelial cancer. Moreover, activation of the androgen receptor and estrogen receptor pathways has been implicated in modulating sensitivity to conventional non-surgical therapy for bladder cancer. This may indicate the possibility of anti-androgenic and anti-estrogenic drugs, apart from their direct anti-tumor activity, to function as sensitizers of such conventional treatment. This article summarizes available data suggesting the involvement of sex hormone receptors, such as androgen receptor, estrogen receptor- $\alpha$, and estrogen receptor- $\beta$, in the progression of urothelial cancer, focusing on their modulation for the efficacy of conventional therapy, and discusses their potential of overcoming therapeutic resistance.
\end{abstract}

Keywords: androgen receptor; estrogen receptor; bladder cancer; chemotherapy; BCG immunotherapy; radiotherapy; urothelial cancer

\section{Introduction}

Urinary bladder cancer, predominantly urothelial carcinoma, has been one of the commonly diagnosed malignancies, especially in men [1]. In addition, the number of deaths from bladder cancer throughout the world has risen from approximately 165,000 in 2012 [2] to 200,000 in 2018 [1]. Interestingly, in contrast to its incidence, the mortality rate among female patients with bladder cancer is higher [1,2]. Intravesical therapy with bacillus Calmette-Guérin (BCG), attenuated bacterial strains derived from Mycobacterium bovis, or chemotherapeutic agents, such as mitomycin $C$ and doxorubicin, has been widely used in the management of non-muscle-invasive (NMI) bladder cancer after transurethral surgery [3]. In those with localized muscle-invasive (MI) bladder cancer, systemic cisplatinbased chemotherapy and/or radiotherapy have been employed before or after radical cystectomy [4-7]. Meanwhile, newly developed immunotherapy with immune checkpoint blockade has been expected to improve the survival of patients with advanced bladder cancer [5-7].

Sex hormone receptors, such as androgen receptor (AR), estrogen receptors (ERs) (i.e., $\mathrm{ER} \alpha, \mathrm{ER} \beta$ ), and progesterone receptor (PR), are a group of steroid receptors that are activated upon binding of cognitive ligands, androgens, estrogens, and progestogens, respectively. Recent findings indicate a vital role of sex hormone receptor signals in the pathogenesis of urothelial cancer, which may be the underlying reasons for the sex-related disparity in bladder cancer. Specifically, AR activation has been implicated in urothelial 
tumorigenesis, whereas conflicting results exist as to the estrogen effects that may be dependent on the functional activity of ER $\alpha$ versus ER $\beta$ in urothelial cells (reviewed in [8]). Particularly, it has been documented, using preclinical models for bladder cancer induced by known carcinogens in humans such as amine [9] and tobacco smoking [10], that AR knockdown results in strong prevention in its development. Moreover, emerging data suggest the association of androgen/estrogen-mediated receptor activity with not only the progression of urothelial tumors, but also the therapeutic efficacy in patients with bladder cancer. By contrast, to the best of our knowledge, no studies have demonstrated direct evidence to indicate the role of PR in bladder cancer [11], although an animal study [12] and a case-control study [13] have implied the preventive effects of progestogens on urothelial tumorigenesis. In this article, we mainly reviewed preclinical and clinical data implying the involvement of sex hormone receptors, particularly AR and ER signals, in modulating sensitivity to conventional non-surgical therapy for bladder cancer.

\section{Sex Hormone Receptor Signaling and Bladder Cancer Progression}

\section{1. $A R$}

AR expression in bladder cancer has been assessed by immunohistochemistry in surgical specimens. The overall immunoreactivity in bladder tumors has been reported to range from $13 \%$ to $54 \%$ [11]. Some of these studies have compared the rates of AR positivity in low-grade vs. high-grade tumors and/or NMI vs. MI tumors [14-24] (Table 1). Of them, four $[14,17,18,24]$ and one [21] studies showed significant or insignificant downregulation and significant up-regulation of AR expression, respectively, in high-grade tumors, while, in others $[16,19,20,23]$, there were no significant differences in AR positivity between low-grade and high-grade tumors. Similarly, five $[14,15,17,18,24]$ and two $[16,21]$ studies showed significant or insignificant down-regulation and insignificant up-regulation, respectively, in MI tumors. Our meta-analysis published in 2017 [25] also demonstrated that AR positivity was significantly lower in high-grade tumors than in low-grade tumors [odds ratio $(\mathrm{OR})=0.575 ; 95 \%$ confidence interval $(\mathrm{CI})=0.421-0.785 ; p<0.001]$, but that there was no significant difference between NMI and MI tumors $(p=0.356)$. These discordant findings on AR levels in various grades/stages of bladder cancer might be due to the use of different antibodies and/or protocols for staining as well as the lack of standardization in scoring. The prognostic value of AR expression in bladder tumors has additionally been assessed in some of these studies, showing conflicting findings. Specifically, AR positivity was significantly or insignificantly associated with better $[17,20]$ and worse $[18,23,24]$ outcomes, while two other studies [16,21] failed to show its prognostic significance. In our meta-analysis [25], AR expression in NMI bladder tumors was found to associate with better recurrence-free survival [hazard ratio $(\mathrm{HR})=0.593 ; 95 \% \mathrm{CI}=0.408-0.860 ; p=0.006$ ], but not with progression-free survival $(p=0.223)$.

The impact of androgens on tumor progression have been assessed in pre-clinical models for bladder cancer. Specifically, androgens, such as dihydrotestosterone (DHT) and methyltrienolone (R1881), induced cell proliferation, migration, and invasion in bladder cancer lines expressing a functional AR [9,26-32]. Correspondingly, gene silencing/knockdown of AR or treatment with AR antagonists, such as flutamide, bicalutamide, and enzalutamide, in these cell lines showed the inhibitory effects $[9,26-31,33]$. Epidermal growth factor (EGF) has also been shown to promote the growth of bladder cancer cells via the AR pathway [28]. Additionally, in mouse xenograft models for bladder cancer, AR inactivation resulted in the retardation of tumor growth [9,26,31]. In a transgenic mouse model where bladder cancer spontaneously developed, bilateral orchiectomy repressed tumor growth, which was restored by DHT supplementation [34].

Potential downstream targets of AR signals in bladder cancer cells have been explored (Figure 1). These molecules/pathways, some of which are transcription factors, include ATF2 [35], $\beta$-catenin/Wnt and its downstream c-myc and cyclin D1 [26,30,36], CD24 [29,33], EGF receptor (EGFR)/ERBB2/AKT/ERK [27], ELK1 [37], FOXO1 [32], IL-6 [31,38], matrix metalloproteinases (MMPs) $[9,26,31,33]$, NF- $\mathrm{KB}$ [39], and vascular endothelial growth factor 
(VEGF) $[9,33]$. Indeed, most of these have been implicated in bladder cancer cell proliferation/apoptosis, cell invasion/metastasis, and/or epithelial-to-mesenchymal transition. These observations may thus represent underlying molecular mechanisms for how AR signals promote urothelial cancer progression.

Table 1. Immunoreactivity for AR in low-grade vs. high-grade and NMI vs. MI bladder cancers and its prognostic significance.

\begin{tabular}{|c|c|c|c|c|c|c|c|}
\hline \multirow{2}{*}{ Author, Year [Ref] } & \multicolumn{3}{|c|}{ Tumor Grade } & \multicolumn{3}{|c|}{ Tumor Stage } & \multirow{2}{*}{$\begin{array}{l}\text { Prognostic } \\
\text { Significance }\end{array}$} \\
\hline & Low-Grade & High-Grade & $p^{\mathrm{a}}$ & NMI & MI & $p^{\mathrm{a}}$ & \\
\hline Boorjian, 2004 [14] & $8 / 9(89 \%)$ & $16 / 33(48 \%)$ & 0.055 & $21 / 28(75 \%)$ & $3 / 14(21 \%)$ & 0.002 & NA \\
\hline Boorjian, 2009 [15] & NA & NA & NA & $13 / 22(59 \%)$ & $11 / 33(33 \%)$ & 0.095 & NA \\
\hline Mir, 2011 [16] & $11 / 90(12 \%)$ & $50 / 382(13 \%)$ & 0.864 & $11 / 126(9 \%)$ & $46 / 305(15 \%)$ & 0.086 & NS \\
\hline Tuygun, 2011 [17] & $46 / 72(64 \%)$ & $25 / 67(37 \%)$ & 0.002 & $64 / 106(60 \%)$ & $7 / 33(21 \%)$ & $<0.001$ & $\begin{array}{c}p=0.095 \\
\text { (RFS/NMI) }\end{array}$ \\
\hline Miyamoto, 2012 [18] & $31 / 56(55 \%)^{b}$ & $48 / 132(36 \%)$ & 0.023 & $49 / 97(51 \%)$ & $30 / 91(33 \%)$ & 0.018 & $\begin{array}{l}p=0.0705 \\
(\mathrm{PFS} / \mathrm{MI})\end{array}$ \\
\hline Jing, 2014 [19] & $22 / 40(55 \%)$ & $9 / 18(50 \%)$ & 0.781 & $22 / 45(49 \%)$ & $9 / 13(69 \%)$ & 0.225 & NA \\
\hline Nam, 2014 [20] & $47 / 120(39 \%)^{b}$ & $16 / 49(33 \%)$ & 0.485 & NA & NA & NA & $p=0.001$ (RFS) \\
\hline Elzamy, 2018 [21] & $7 / 48(15 \%)^{b}$ & $30 / 58(52 \%)$ & $<0.001$ & $5 / 27(19 \%)$ & $32 / 79(41 \%)$ & 0.060 & NS \\
\hline Tyagi, 2019 [22] & NA & NA & NA & $17 / 38(45 \%)$ & $22 / 34(65 \%)$ & 0.103 & NA \\
\hline Yonekura, 2019 [23] & $11 / 26(42 \%)$ & $9 / 14(64 \%)$ & 0.320 & NA & NA & NA & $\begin{array}{c}p<0.05 \\
\text { (RFS\&PFS/NMI) }\end{array}$ \\
\hline Toren, 2020 [24] & $76 / 121(63 \%)^{c}$ & $79 / 194(41 \%)^{c}$ & $<0.001$ & $95 / 150(63 \%)$ & $61 / 167$ (37\%) & $<0.001$ & $\begin{array}{c}p=0.03 \\
(\mathrm{RFS} / \mathrm{RC})\end{array}$ \\
\hline
\end{tabular}

NMI, non-muscle-invasive; MI, muscle-invasive; NA, not available; NS, not significant; RFS, recurrence-free survival; PFS, progression-free survival; RC, radical cystectomy cases. ${ }^{a}$ We calculated two-tailed $p$ values, using Fisher's exact test. ${ }^{\mathrm{b}}$ Cases of papillary urothelial neoplasm of low malignant potential (PUNLMP) are included. ${ }^{c}$ Low-grade $=$ Grades $1-2$ vs. High-grade $=$ Grade 3.

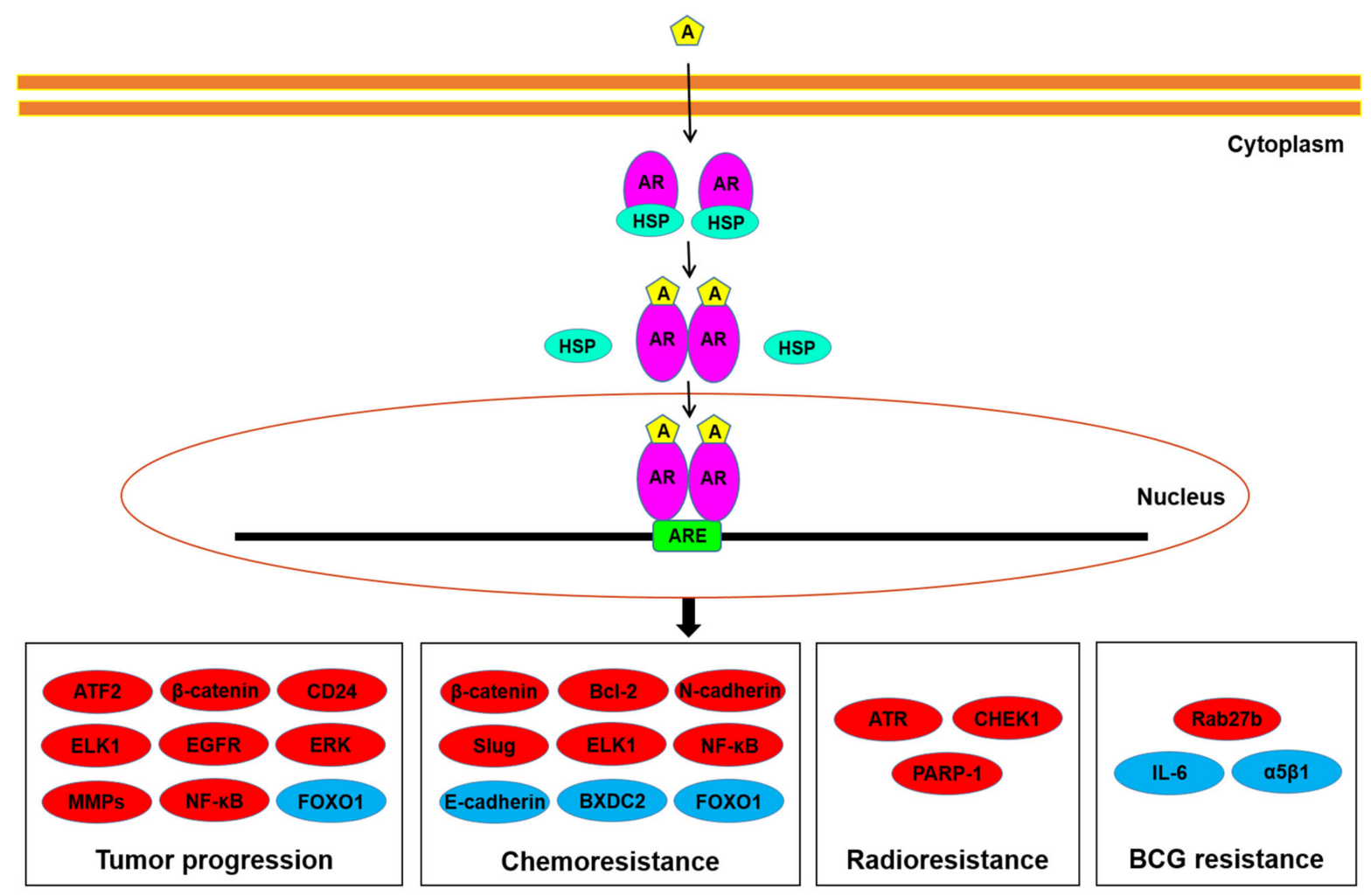

Figure 1. AR signaling in bladder cancer cells. Androgens have been suggested to induce tumor progression, as well as resistance to conventional non-surgical therapy, through the AR pathway via up-regulating (red) or down-regulating (blue) the molecules listed. A, androgen; ARE, androgen response element; HSP, heat shock protein. 


\subsection{ERs}

As aforementioned, two classes of nuclear ERs exist in humans: ER $\alpha$ and ER $\beta$ encoded by ESR1 and ESR2, respectively. The binding affinity of the major estrogen, $17 \beta$-estradiol (E2), for the ER $\alpha$ vs. ER $\beta$ is similar, while some ER agonists and antagonists preferentially bind to one (e.g., estrone/raloxifene to ER $\alpha$ ) [40]. More importantly, these two receptors may have different biological functions.

The expression of ER $\alpha$ and ER $\beta$ in bladder tumors has been immunohistochemically investigated in surgical specimens. The overall positive rates of ER $\alpha$ and ER $\beta$ ranged from $1 \%$ to $38 \%$ and $22 \%$ to $100 \%$, respectively [11,41]. Tables 2 and 3 summarize the findings from studies comparing the rates of ER $\alpha / E R \beta$ positivity in low-grade vs. high-grade tumors and/or NMI vs. MI tumors [17,18,20,41-47]. The expression of ER $\alpha$ was significantly down-regulated [18] or slightly up-regulated [41] in high-grade/MI tumors, while another study [42] showed no differences in its positivity. In addition, no prognostic role of ER $\alpha$ expression in bladder cancer has been documented [18,42]. Significant or insignificant up-regulation of ER $\beta$ expression in high-grade and/or MI tumors have been reported in more than half of the studies [18,20,43,44,47], whereas the other study [45] oppositely showed significant down-regulation. ER $\beta$ expression was also strongly associated with worse prognosis $[17,18,20]$, while in one study [46], strong ER $\beta$ expression tended to be associated with better outcomes. In our meta-analysis [25], ER $\beta$ expression was found to be significantly up-regulated in high-grade $(\mathrm{OR}=2.169 ; 95 \% \mathrm{CI}=1.583-2.971 ; p<0.001)$ or MI $(\mathrm{OR}=3.104 ; 95 \% \mathrm{CI}=2.081-4.631 ; p<0.001)$ tumors, compared with low-grade or NMI tumors, respectively, and was associated with the risk of disease recurrence $(\mathrm{HR}=1.573$; $95 \% \mathrm{CI}=1.102-2.247 ; p=0.013)$ or progression $(\mathrm{HR}=2.236 ; 95 \% \mathrm{CI}=1.189-4.205 ; p=0.089)$ in patients with NMI tumor.

Inconsistent data on the immunoreactivity for the ER $\alpha$ and ER $\beta$ in bladder tumor samples have thus been reported. Remarkably, the specificity of ER antibodies has been questioned [48,49]. In particular, only a few of commercially available anti-ER $\beta$ antibodies have been found to specifically target ER $\beta$ in immunostaining (and/or immunoblotting). Accordingly, many of the studies described above, including one [46] showing $100 \%$ positivity in a total of 313 tumors using PPG5/10, which has been found to not even target ER $\beta[48,49]$, as well as some of others, particularly with ER $\beta$ knockdown in cell lines described below, may not be credible.

The effects of ER ligands on tumor growth have been assessed, using preclinical models for bladder cancer. In ER $\alpha$-positive bladder cancer lines, E2 induced cell proliferation, while selective ER modulators, including tamoxifen and raloxifene, as well as a pure ER antagonist ICI 182,780, inhibited it [45,50,51]. Tamoxifen and raloxifene have also been shown to inhibit the growth of ER $\alpha$-negative/ER $\beta$-positive bladder cancer cells and their xenograft tumors [44,51-53], while raloxifene failed to significantly affect that of ER $\alpha / E R \beta$ knockdown lines [51]. Thus, activation of ER signals overall appears to be associated with the promotion of urothelial cancer progression. More specifically, selective agonists for $\mathrm{ER} \alpha$ (i.e., propyl-pyrazole-triol) and ER $\beta$ (i.e., diatylpropionitrile) increased the cell proliferation of ER $\alpha$-positive/ER $\beta$-positive bladder cancer lines, but not those expressing an ER $\alpha$-siRNA and an ER $\beta$-siRNA, respectively [50]. Moreover, treatment with a selective $E R \beta$ antagonist (i.e., PHTPP) or knockdown of ER $\beta$ resulted in the suppression of cell growth $[54,55]$. By contrast, ER $\alpha$ knockdown was found to induce the growth of bladder cancer cells and their xenografts in mice [56], suggesting the inhibitory role of ER $\alpha$ in urothelial cancer progression. In accordance with these findings, a positive correlation between the expression of UGT1A, which was known to function as a tumor suppressor, and ER $\alpha$ levels in a urothelial cell line and bladder cancer specimens were observed, while UGT1A and ER $\beta$ expression was inversely correlated [57]. In addition, diatylpropionitrile could inhibit the migration and invasion of bladder cancer cells [58], suggesting the opposite function of $E R \beta$ in urothelial cancer. In addition, at least two prospective clinical trials have been conducted to assess the efficacy of tamoxifen in bladder cancer patients without 
(NCT02197897) or with (NCT00710970) prior chemotherapy, but no favorable effects have been reported.

Table 2. Immunoreactivity for ER $\alpha$ in low-grade vs. high-grade and NMI vs. MI bladder cancers and its prognostic significance.

\begin{tabular}{cccccccc}
\hline \multirow{2}{*}{ Author, Year [Ref] } & \multicolumn{3}{c}{ Tumor Grade } & \multicolumn{2}{c}{ Tumor Stage } & \multicolumn{2}{c}{$\begin{array}{c}\text { Prognostic } \\
\text { Significance }\end{array}$} \\
\cline { 2 - 6 } & Low-Grade & High-Grade & $p^{\text {a }}$ & NMI & MI & $p^{\text {a }}$ & NS \\
\hline Miyamoto, 2012 [18] & $21 / 56(38 \%)^{\mathrm{b}}$ & $30 / 132(23 \%)$ & 0.048 & $34 / 97(35 \%)$ & $17 / 91(19 \%)$ & 0.014 & NA \\
\hline Imai, 2019 [41] & $20 / 63(32 \%)^{\mathrm{c}}$ & $28 / 62(45 \%)^{\mathrm{c}}$ & 0.143 & $26 / 81(32 \%)$ & $22 / 44(50 \%)$ & 0.056 & \\
\hline Bernardo, 2020 [42] & $2 / 12(17 \%)$ & $12 / 68(18 \%)$ & 1.000 & $7 / 40(18 \%)$ & $7 / 40(18 \%)$ & 1.000 & NS \\
\hline
\end{tabular}

NMI, non-muscle-invasive; MI, muscle-invasive; NS, not significant; NA, not available. ${ }^{\text {a }}$ We calculated two-tailed $p$ values, using Fisher's exact test. ${ }^{\mathrm{b}}$ Cases of papillary urothelial neoplasm of low malignant potential (PUNLMP) are included. ${ }^{\mathrm{c}}$ Low-grade $=$ Grades $1-2 \mathrm{vs}$. High-grade $=$ Grades $3-4$.

Table 3. Immunoreactivity for ER $\beta$ in low-grade vs. high-grade and NMI vs. MI bladder cancers and its prognostic significance.

\begin{tabular}{|c|c|c|c|c|c|c|c|}
\hline \multirow{2}{*}{ Author, Year [Ref] } & \multicolumn{3}{|c|}{ Tumor Grade } & \multicolumn{3}{|c|}{ Tumor Stage } & \multirow{2}{*}{$\begin{array}{l}\text { Prognostic } \\
\text { Significance }\end{array}$} \\
\hline & Low-Grade & High-Grade & $p^{\mathrm{a}}$ & NMI & MI & $p^{a}$ & \\
\hline Croft, 2005 [43] & $6 / 50(12 \%)^{b}$ & $14 / 42(33 \%)^{b}$ & 0.021 & NA & NA & NA & NA \\
\hline Shen, 2006 [44] & $66 / 114(58 \%)^{b}$ & $67 / 96(70 \%)^{b}$ & 0.085 & $78 / 145(54 \%)$ & $47 / 59(80 \%)$ & $<0.001$ & NA \\
\hline Kontos, 2010 [45] & $54 / 57(95 \%)^{\mathrm{b}}$ & $30 / 54(56 \%)^{b}$ & $<0.001$ & $25 / 30(83 \%)$ & $22 / 41(54 \%)$ & 0.011 & NA \\
\hline Tuygun, 2011 [17] & $16 / 72(22 \%)$ & $21 / 67(31 \%)$ & 0.253 & $28 / 106(26 \%)$ & $12 / 33(36 \%)$ & 0.279 & $\begin{array}{c}p=0.035 \\
(\mathrm{PFS} / \mathrm{NMI})\end{array}$ \\
\hline Miyamoto, 2012 [18] & $16 / 56(29 \%)^{c}$ & $77 / 132(58 \%)$ & $<0.001$ & $39 / 97(34 \%)$ & $60 / 91(66 \%)$ & $<0.001$ & $\begin{array}{c}p<0.01 \\
\text { (PFS/NMI) } \\
p<0.01 \\
\text { (PFS\&CSS } / \mathrm{MI})\end{array}$ \\
\hline Nam, 2014 [20] & $32 / 120(27 \%)^{c}$ & $20 / 49(41 \%)$ & 0.098 & NA & NA & NA & $\begin{array}{c}p<0.05 \\
\text { (RFS\&PFS) }\end{array}$ \\
\hline Tan, 2015 [46] & $28 / 28(100 \%)^{d}$ & $\underset{\mathrm{d}}{262 / 262(100 \%)}$ & 1.000 & 95/95 (100\%) & $\begin{array}{c}216 / 216 \\
(100 \%)\end{array}$ & 1.000 & $p=\frac{0.055-0.087}{(\mathrm{CSS})}$ \\
\hline Nguyen, 2017 [47] & $2 / 6(33 \%)$ & $16 / 24(67 \%)$ & 0.184 & $3 / 11(27 \%)$ & $15 / 19(79 \%)$ & 0.009 & NS \\
\hline Bernardo, 2020 [42] & $11 / 12(92 \%)$ & $62 / 68(91 \%)$ & 1.000 & $36 / 40(90 \%)$ & $37 / 40(93 \%)$ & 1.000 & NA \\
\hline
\end{tabular}

NMI, non-muscle-invasive; MI, muscle-invasive; NA, not available; NS, not significant; RFS, recurrence-free survival; PFS, progression-free survival; CSS, cancer-specific survival. a We calculated two-tailed $p$ values, using Fisher's exact test. ${ }^{b}$ Low-grade $=$ Grades $1-2$ vs. High-grade $=$ Grade $3 .{ }^{c}$ Cases of papillary urothelial neoplasm of low malignant potential (PUNLMP) are included. ${ }^{\mathrm{d}}$ Low-grade $=$ Grades $1-2$ vs. High-grade $=$ Grades $3-4$.

Underlying molecular mechanisms for ER function in bladder cancer have further been investigated (Figure 2). The oncogenic molecules/pathways potentially modulated by ER signaling in bladder cancer cells include AKT/ERK [50,55,56] and E-cadherin/Ncadherin [58], as well as MCM2 [59], which involves the initiation of DNA replication. The increase in apoptosis by raloxifene was also shown to mediate via inducing the cleavage of caspase-3 and BAD [51,52]. In our recent study described above [32], we demonstrated that ER $\beta$ could bind to the promoter region of FOXO1, a transcription factor functioning as a tumor suppressor, in bladder cancer cells, and that E2 treatment inactivated FOXO1 in ER $\alpha$-negative/ER $\beta$-positive cells, resulting in the up-regulation of MMP-2 and VEGF as well as down-regulation of p21 and p27. Recent studies have also indicated the link between $E R \alpha / E R \beta$ activation and the modulation of microRNA, circular RNA, and enhancer RNA [60-64], all of which are known to involve bladder cancer progression. 


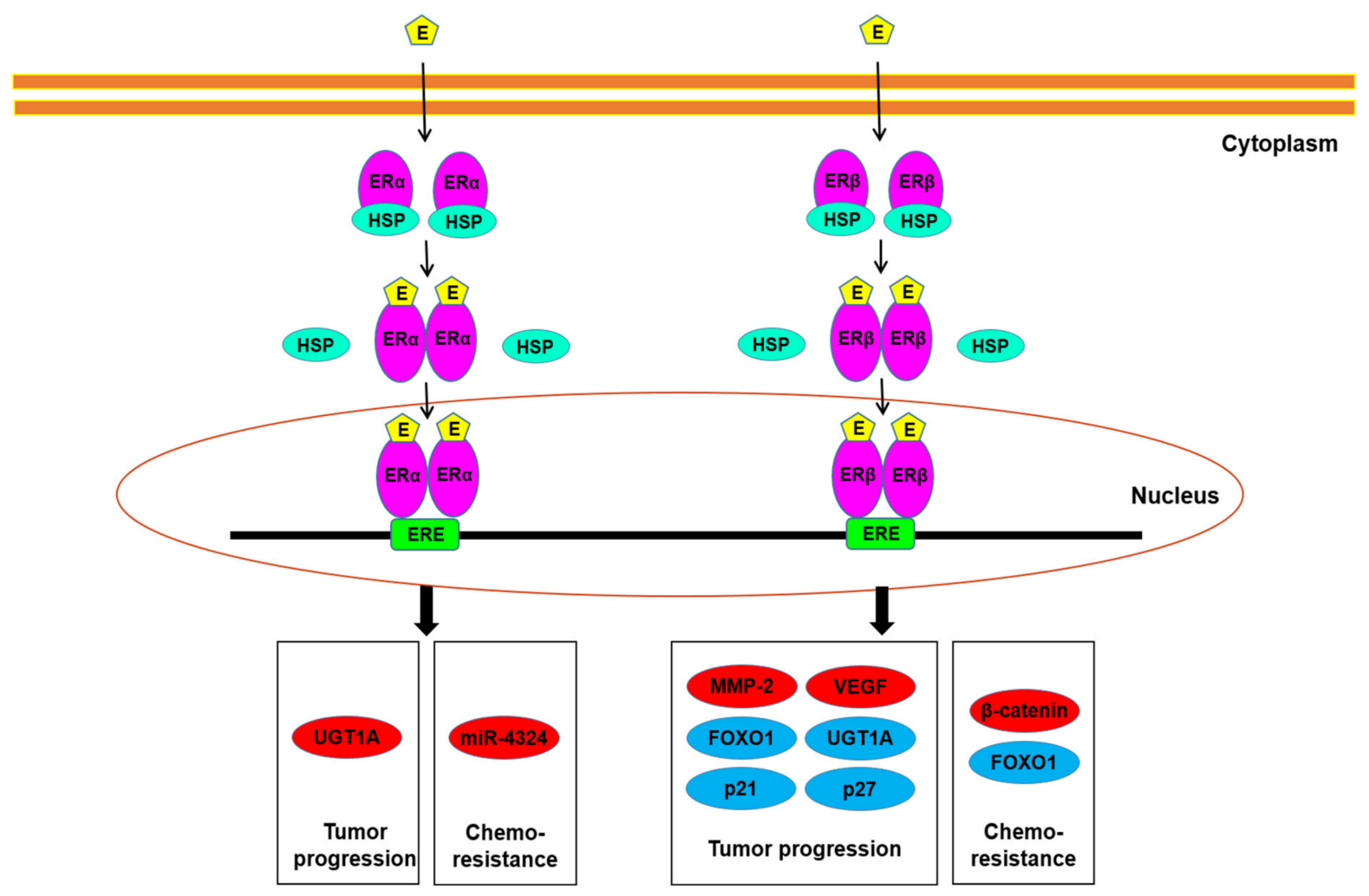

Figure 2. ER signaling in bladder cancer cells. Estrogens have been suggested to modulate tumor progression, as well as chemoresistance, through the ER $\alpha$ and/or ER $\beta$ pathways via up-regulating (red) or down-regulating (blue) the molecules listed. E, estrogen; ERE, estrogen response element; HSP, heat shock protein.

\section{Sex Hormone Receptor Signaling and Sensitivity to Conventional Non-Surgical Treatment for Bladder Cancer}

Conventional non-surgical therapy against bladder cancer includes systemic chemotherapy, intravesical pharmacotherapy with anti-cancer agents or BCG, radiotherapy, and immunotherapy with immune checkpoint inhibitors. Although these are quite effective in some patients, bladder cancer, especially MI disease, remains lethal [65]. The development of strategies for not only overcoming therapeutic resistance where underlying mechanisms are poorly understood, but also predicting its sensitivity, is thus urgently required. Meanwhile, sex hormone receptor signals have been implicated in modulating sensitivity to conventional therapy for bladder cancer. The main findings in preclinical studies $[22,30,32,37,55,66-79]$ suggesting this are summarized in Table 4. 
Table 4. Preclinical studies suggesting the involvement of AR/ER signaling in modulating sensitivity to conventional therapy for bladder cancer.

\begin{tabular}{|c|c|c|c|c|c|}
\hline Author, Year [Ref] & $\begin{array}{c}\text { Conventional } \\
\text { Therapy }\end{array}$ & Receptor & Design/Model & Main Findings & $\begin{array}{l}\text { Molecules/Pathways } \\
\text { Involved }\end{array}$ \\
\hline $\mathrm{Pu}, 1995[66]$ & $\begin{array}{c}\text { CT (CIS, DOX, MTX, } \\
\text { VBL) }\end{array}$ & ER & $\begin{array}{l}\text { T24/NTUB1/BFTCC905 } \\
\text { cell viability }\end{array}$ & $\begin{array}{l}\text { TAM } \uparrow \text { growth } \\
\text { inhibition }\end{array}$ & NA \\
\hline $\mathrm{Pu}, 1996$ [67] & $\begin{array}{l}\text { CT (DOX, MMC, } \\
\text { TTP) }\end{array}$ & ER & $\begin{array}{l}\text { TSGH8301/HTB9 } \\
\text { cell viability }\end{array}$ & $\begin{array}{l}\text { TAM } \uparrow \text { growth } \\
\text { inhibition }\end{array}$ & NA \\
\hline Shiota, 2012 [30] & CT (DOX) & AR & UMUC3 cell viability & $\begin{array}{c}\text { DHT } \downarrow \text { sensitivity } \\
\text { AR-siRNA } \\
\uparrow \text { sensitivity }\end{array}$ & NA \\
\hline $\begin{array}{l}\text { Kawahara, } 2015 \text { [37] } \\
\text { Kawahara, } 2015 \text { [68] }\end{array}$ & CT (CIS) & AR & UMUC3 cell viability & $\begin{array}{c}\text { DHT } \uparrow \text { ELK1 } \\
\text { ELK1-inactivation } \\
\uparrow \text { sensitivity }\end{array}$ & ELK1 \\
\hline Shang, 2015 [69] & $\mathrm{BCG}$ & AR & $\begin{array}{c}\text { 253J/T24 cell } \\
\text { viability } \\
\text { BBN-induced tumor } \\
\text { in mice }\end{array}$ & $\begin{array}{l}\text { ASC-J9/HF } \uparrow \text { growth } \\
\text { inhibition }\end{array}$ & integrin $\alpha 5 \beta 1$ \\
\hline Takeuchi, 2015 [70] & CT (GEM) & ER & $\begin{array}{l}\text { 5637/RT4/TCCSUP } \\
\text { cell viability }\end{array}$ & $\begin{array}{l}\text { TAM } \uparrow \text { growth } \\
\text { inhibition }\end{array}$ & NA \\
\hline Kashiwagi, 2016 [71] & $\mathrm{CT}(\mathrm{CIS})$ & AR & $\begin{array}{l}\text { 5637/647V/UMUC3 } \\
\text { cell viability }\end{array}$ & $\begin{array}{c}\text { AR-overexpression } \\
\downarrow \text { sensitivity } \\
\text { AR-knockdown/HF } \\
\uparrow \text { sensitivity }\end{array}$ & $\mathrm{NF}-\kappa \mathrm{B}$ \\
\hline Kameyama, 2017 [72] & CT (GEM) & AR & T24 cell viability & ENZ $\uparrow$ sensitivity & cyclin D1 \\
\hline Ide, 2018 [73] & RT & $\mathrm{AR}$ & $\begin{array}{l}\text { 5637/647V/UMUC3 } \\
\text { cell viability }\end{array}$ & $\begin{array}{c}\text { AR overexpres- } \\
\text { sion/DHT } \\
\downarrow \text { sensitivity } \\
\text { AR-knockdown/HF } \\
\uparrow \text { sensitivity } \\
\end{array}$ & ATR, CHEK1, PARP1 \\
\hline Huang, 2019 [55] & CT (CIS, DOX, MMC) & $\mathrm{AR}$ & $\begin{array}{c}\text { J82/TCCSUP cell } \\
\text { viability } \\
\text { J82 mouse xenograft }\end{array}$ & ASC-J9 $\uparrow$ sensitivity & $\mathrm{BAX}, \mathrm{BCL} 2, \mathrm{p} 21$ \\
\hline Long, 2019 [74] & CT (CIS) & $\mathrm{ER} \beta$ & $\begin{array}{l}5637 / \mathrm{T} 24 \text { cell } \\
\text { viability }\end{array}$ & $\begin{array}{c}\text { Co-culture of CAF } \\
\uparrow E R \beta \text { expression } \\
\downarrow \text { sensitivity }\end{array}$ & IGF1 \\
\hline Sekino, 2019 [75] & $\mathrm{CT}(\mathrm{CIS})$ & $\mathrm{AR}$ & $\begin{array}{l}\text { RT112/UMUC3 cell } \\
\text { viability }\end{array}$ & $\begin{array}{c}\text { AR-overexpression } \\
\downarrow \text { sensitivity }\end{array}$ & Uc.63+ \\
\hline Tyagi, 2019 [22] & $\mathrm{CT}(\mathrm{CIS})$ & AR & $\begin{array}{l}\text { TCCSUP cell viabil- } \\
\text { ity/migration/invasion }\end{array}$ & ENZ $\uparrow$ sensitivity & EMT \\
\hline Goto, 2020 [76] & $\mathrm{CT}(\mathrm{CIS})$ & $\mathrm{ER} \beta$ & $\begin{array}{l}\text { 5637/647V /UMUC3 } \\
\text { cell viability }\end{array}$ & $\begin{array}{c}\text { ER } \beta- \\
\text { knockdown/TAM } \\
\uparrow \text { sensitivity }\end{array}$ & $\beta$-catenin \\
\hline $\begin{array}{l}\text { Ide, } 2020 \text { [32] } \\
\text { Ide, } 2020 \text { [77] }\end{array}$ & $\mathrm{CT}(\mathrm{CIS})$ & $\mathrm{AR} / \mathrm{ER} \beta$ & $\begin{array}{l}\text { 5637/647V /UMUC3 } \\
\text { cell viability }\end{array}$ & $\begin{array}{c}\text { AR/ER } \beta \text { inactivate } \\
\text { FOXO1 } \\
\text { FOXO1-inactivation } \\
\downarrow \text { sensitivity }\end{array}$ & FOXO1 \\
\hline Mizushima, 2020 [78] & $\mathrm{BCG}$ & AR & $\begin{array}{l}\text { 5637/MB49/UMUC3 } \\
\text { cell viability }\end{array}$ & $\begin{array}{c}\text { AR- } \\
\text { overexpression/R1881 } \\
\downarrow \text { sensitivity } \\
\text { AR-knockdown } \\
\uparrow \text { sensitivity }\end{array}$ & Rab27b \\
\hline Jiang, 2021 [79] & $\mathrm{CT}(\mathrm{CIS})$ & $\mathrm{AR}$ & $\begin{array}{l}5637 / \text { UMUC3 cell } \\
\text { viability }\end{array}$ & $\begin{array}{c}\text { AR- } \\
\text { overexpression/DHT } \\
\downarrow \text { BXDC2 } \\
\text { BXDC2-knockdown } \\
\downarrow \text { sensitivity }\end{array}$ & BXDC2 \\
\hline
\end{tabular}

$\uparrow$ : increase; $\downarrow$ : decrease; BBN: N-butyl-N-(4-hydroxybutyl)nitrosamine; BCG: intravesical bacillus Calmette-Guérin immunotherapy; CAF: cancer-associated fibroblasts; CIS: cisplatin; CT: chemotherapy; DHT: dihydrotestosterone; EMT: epithelial-to-mesenchymal transition; ENZ: enzalutamide; DOX: doxorubicin; GEM: gemcitabine; HF: hydroxyflutamide; MMC: mitomycin C; MTX: methotrexate; NA, not available or not assessed; RT: radiotherapy; TAM: tamoxifen; TTP: thiotepa; VBL, vinblastine.

\subsection{Chemotherapy}

Cisplatin-based combination chemotherapy (e.g., MVAC: methotrexate/vinblastine/ doxorubicin/cisplatin; GC: gemcitabine/cisplatin) remains the standard of care in patients with locally advanced or metastatic bladder cancer. These regimens are also widely used 
prior to radical cystectomy as neoadjuvant therapy. However, a considerable number of patients either fail to respond or eventually acquire resistance. In addition, several chemotherapeutic agents, such as doxorubicin, mitomycin C, and thiotepa, have been given intravesically to those with superficial bladder tumor following transurethral surgery primarily as prophylactic therapy.

In bladder cancer specimens from patients who had subsequently received cisplatinbased neoadjuvant chemotherapy, there was a correlation between AR immunoreactivity and chemosensitivity (i.e., AR-positive in $21 \%$ of responders vs. $45 \%$ of non-responders, $p=0.087$ ) [72]. In bladder cancer sublines resistant to cisplatin [71,80], as well as gemcitabine [72], AR expression has been found to be considerably elevated, compared to control or parental cells. These findings suggest the involvement of AR signals in chemoresistance in bladder cancer.

Cell proliferation assay data indeed showed that bladder cancer lines with AR overexpression [75] or androgen treatment [71] were more resistant to cisplatin. Correspondingly, AR silencing/knockdown or antagonist (e.g., hydroxyflutamide, enzalutamide) treatment enhanced the cytotoxic effects of cisplatin in bladder cancer cells, even resistant sublines [22,71]. Enzalutamide was also shown to induce apoptosis and prevent cell migration/invasion in the presence of cisplatin [22]. Mechanistically, enzalutamide treatment was associated with increases in the expression of BAX, cleaved caspase-3, cleaved PARP, and an epithelial marker E-cadherin, and decreases in that of Bcl-2 and mesenchymal markers (e.g., $\beta$-catenin, $\mathrm{N}$-cadherin, Slug, vimentin), although there appeared to be no significant differences in their expression between cisplatin + enzalutamide vs. cisplatin or enzalutamide alone [22].

Similar findings have been reported with other anti-cancer agents. Specifically, ARpositive bladder cancer cells with DHT treatment or AR silencing were shown to be less or more, respectively, sensitive to doxorubicin, compared with controls [30]. Additionally, in a gemcitabine-resistant bladder cancer subline, enzalutamide was found to restore its sensitivity while reducing the expression of cyclin D1 [72]. A more recent study demonstrated that ASC-J $9^{\circledR}$, an AR degradation enhancer, could increase sensitivity to not only cisplatin and doxorubicin, but also mitomycin C in AR-positive bladder cancer cells [55]. These findings indicate that activation of AR signaling is associated with chemoresistance in bladder cancer.

We have further explored how AR signals modulate chemosensitivity. There were close correlations of AR expression/activity with those of NF- $\mathrm{kB}$, which is considered to be a key molecule for cisplatin resistance, in bladder cancer cells [39,72]. We have also found that androgen up-regulates the expression of a $c$-fos proto-oncogene regulator ELK1 in bladder cancer cells [37] and that ELK1 inactivation via stable expression of a shRNA or treatment with a selective $\alpha 1$-blocker silodosin increases sensitivity to cisplatin [68]. Immunohistochemistry in surgical specimens form patients subsequently undergoing cisplatin-based neoadjuvant chemotherapy, phospho-ELK1 positivity was significantly $(p=0.039)$ higher in those from non-responders $(71 \%)$ than in those from responders (38\%) [68]. We recently demonstrated that androgen/AR could down-regulate the expression of BXDC2, also named BRIX1, which involves ribosome biogenesis, in bladder cancer cells, and loss of BXDC2 in cell lines and surgical specimens was associated with cisplatin resistance [79]. Furthermore, an ERK activator reduced BXDC2 expression in bladder cancer cells, while BXDC2 knockdown failed to affect phospho-ERK expression [79], suggesting cisplatin resistance via the AR $\rightarrow$ ERK $\rightarrow$ BXDC2 signaling pathway.

Similar to our immunohistochemistry data on AR [71], we recently demonstrated that the rate of ER $\beta$ positivity in transurethral resection specimens was significantly lower in responders to cisplatin-based neoadjuvant chemotherapy than in non-responders $(37 \%$ vs. $71 \%, p=0.016)$, especially in female patients $(20 \%$ of responders vs. $100 \%$ of nonresponders, $p=0.048)$, but not in males ( $42 \%$ of responders vs. $65 \%$ of non-responders, $p=0.142$ ) [76]. Meanwhile, elevated ER $\beta$ expression in adjacent normal bladder tissues was strongly associated with a worse prognosis in patients undergoing cisplatin-based 
chemotherapy [74]. Two early studies in bladder cancer lines by one group showed that treatment with tamoxifen, along with methotrexate, vinblastine, doxorubicin, cisplatin, mitomycin C, or thiotepa, more strongly inhibited their proliferation, compared to that with each chemotherapeutic drug alone [66,67]. However, in these assays, the combination effects were not directly compared with that of tamoxifen alone, and it might therefore be unable to conclude that tamoxifen could increase sensitivity to each cytotoxic agent. The same group conducted a clinical trial of MVAC plus a high dose $\left(200 \mathrm{mg} / \mathrm{m}^{2} /\right.$ day, days 1-4) of tamoxifen in 30 patients with advanced bladder cancer, showing the comparable response rate to that known for conventional MVAC therapy, but no control arm with MVAC alone was compared [81]. In an additional in vitro study, gemcitabine combined with tamoxifen showed stronger inhibitory effects on the growth of bladder cancer cells than gemcitabine or tamoxifen alone [70], but the rates of inhibition by tamoxifen in the absence versus presence of gemcitabine were not directly compared. In a recent study, co-culture of cancer-associated fibroblasts was shown to induce ER $\beta$ expression in bladder cancer cells while reducing the cytotoxicity of cisplatin [74]. We further demonstrated that tamoxifen treatment or ER $\beta$ knockdown in ER $\alpha$-negative bladder cancer cells resulted in the enhancement of cisplatin sensitivity [76]. Moreover, in the cisplatin-resistant sublines, ER $\beta$ expression was considerably elevated, while E2 induced the expression and activity of $\beta$-catenin which was known to involve cisplatin resistance [76]. Thus, activation of ER, especially ER $\beta$, is likely associated with chemoresistance. Additionally, in a study showing that ER $\alpha$ could induce the expression of miR-4324 via binding to its promoter in bladder cancer cells, overexpression of miR-4324 significantly induced the cytotoxic effects of doxorubicin [63], suggesting an association between ER $\alpha$ activation and increased sensitivity to doxorubicin.

As aforementioned, both androgen and estrogen could inactivate a tumor suppressor FOXO1 via the AR and ER $\beta$ pathways, respectively, in bladder cancer cells [32]. We further found that silencing of FOXO1 or treatment with an FOXO1 inhibitor in bladder cancer cells resulted in the reduction of sensitivity to cisplatin [77]. The expression of an inactivated form phospho-FOXO1 was considerably up-regulated in cisplatin-resistant cells, compared with control cells, and phospho-FOXO1 expression in transurethral resection specimens from patients undergoing cisplatin-based neoadjuvant chemotherapy was more often seen in non-responders $(67.9 \%)$ than in responders (38.9\%) [77]. FOXO1 inactivation could thus be an underlying mechanism for chemoresistance in bladder cancer induced by AR and/or ER $\beta$ signals.

A phase $1 / 1 \mathrm{~b}$ clinical trial has been conducted to assess if AR modulation enhances the efficacy of chemotherapy (NCT02300610; completed in December 2012). In a total of 10 patients with urothelial cancer receiving standard doses of gemcitabine and cisplatin, oral enzalutamide ( 80 or $160 \mathrm{mg}$ ) was added. Although some of the patients with $160 \mathrm{mg}$ enzalutamide showed partial response, no control arm with no enzalutamide treatment was compared.

\subsection{Radiotherapy}

In selected patients with MI bladder cancer, radiotherapy combined with chemotherapy led to survival rates comparable to those undergoing radical cystectomy [4]. Specifically, in these patients, trimodal therapy consisting of either transurethral resection or partial cystectomy followed by radiotherapy with concurrent chemotherapy is currently considered to yield the best oncologic outcomes $[4,65]$. Although the trimodal therapy may increase quality-adjusted life years, current data on overall survival or disease-specific survival are still in favor of radical cystectomy [82]. Thus, the development of the novel radiosensitization strategies is required to replace radical cystectomy with radiotherapy as a gold standard option for some MI bladder cancers.

We showed that bladder cancer lines endogenously or exogenously expressing a full-length wild-type human AR were significantly less sensitive to irradiation, compared with AR knockdown or control AR-negative sublines, respectively [73]. Correspondingly, 
DHT or hydroxyflutamide treatment in AR-positive bladder cancer lines significantly reduced or induced, respectively, the cytotoxic effects of irradiation. Meanwhile, radiationresistant sublines established following 2 Gy ionizing radiation six times/two weeks showed significant elevation in the expression of not only DNA repair genes, such as ATR, CHEK1, and PARP-1, but also AR mRNA/protein. In mouse xenograft models for bladder cancer, considerable increases in radiosensitivity by AR knockdown or antiandrogen treatment were verified. Mechanistically, AR inactivation via knockdown or hydroxyflutamide treatment was found to be associated with a delay in DNA double-strand break repair (e.g., $\gamma \mathrm{H} 2 \mathrm{AX}$ resolution) $4-24 \mathrm{~h}$ after irradiation. Additionally, in irradiated AR-positive cells, DHT induced the expression of the DNA repair genes, which was restored by hydroxyflutamide. Our findings suggest that AR activity is inversely associated with radiosensitivity in bladder cancer and that concurrent androgen deprivation may function as a sensitizer of irradiation, especially in patients with AR-positive tumor.

In a recent prospective trial (NCT04282876; started in February 2020), patients with MI bladder cancer undergoing radiotherapy are being recruited. A group of these patients is randomized to simultaneously receive a gonadotropin-releasing hormone antagonist (i.e., degarelix) as chemical castration. Primary outcome measures include bladder fibrosis 3 months after irradiation, but oncologic outcomes will not appear to be compared.

\subsection{Immunotherapy}

Intravesical BCG immunotherapy has been widely used for the treatment of urothelial carcinoma in situ and the prevention of disease recurrence after transurethral resection of NMI tumors. Interestingly, although data are conflicting, male [83] or female [84] bladder cancer patients have been shown to be considerably less sensitive to BCG therapy, suggesting the involvement of sex hormone receptor signals in BCG sensitivity.

In an earlier study, DHT was found to inhibit the expression and transactivation of IL-6 induced by BCG treatment in bladder cancer cells [38]. Another study showed that hydroxyflutamide and ASC-J9 increased the expression level of BCG-mediated integrins (e.g., $\alpha 5 \beta 1$ ) and intake of BCG in bladder cancer cells, as well as recruitment of monocytes/macrophages [69]. BCG, along with each AR inhibitor, also more strongly inhibited the growth of bladder cancer cells and chemical carcinogen N-butyl-N-(4-hydroxybutyl) nitrosamine-induced bladder tumors in mice, compared with BCG or AR inhibitor alone [69]. These findings implied that AR signaling might contribute to modulating sensitivity to BCG therapy. We then demonstrated direct evidence to indicate the link between AR activation and BCG resistance [78]. AR knockdown or overexpression in bladder cancer lines was associated with considerable induction or reduction, respectively, in intracellular BCG quantity and BCG cytotoxicity. AR expression was considerably higher in BCGresistant bladder cancer cells following repeating exposure to BCG for over six months, compared with control cells, and AR positivity immunohistochemically determined in NMI bladder cancer specimens from patients who had subsequently undergone intravesical BCG immunotherapy was strongly associated with worse outcomes, compared to those with AR-negative tumor. We also performed DNA microarray screening and identified Rab27b, a small GTPase known to mediate bacterial exocytosis, which was up-regulated in BCG-resistant cells and down-regulated in AR knockdown cells. Indeed, knockdown/overexpression of Rab27b or its known effector SYTL3, as well as treatment with GW4869 known to inhibit Rab27b-dependent secretion, was found to considerably modulate BCG quantity in bladder cancer cells, as well as its cytotoxicity in vitro and in vivo. In addition, Rab27b positivity in the same cohort of patients with BCG therapy was associated with a significantly higher risk of tumor recurrence. Thus, our findings suggest that AR signaling reduces the efficacy of BCG therapy, presumably via modulating Rab27b-induced exocytosis in bladder cancer cells.

The impact of ER signaling on the efficacy of BCG therapy in bladder cancer has also been investigated. In ER $\alpha$-positive/ER $\beta$-positive bladder cancer cells, E2 reduced BCG attachment and internalization as well as monocyte/macrophage recruitment, whereas 
tamoxifen and a pure anti-estrogen ICI 182,780 reversed the estrogen effect [85]. These anti-estrogens were also found to enhance the cytotoxic effects of BCG in cell line and mouse models for bladder cancer [85]. In addition, a phase 2 randomized clinical trial is ongoing to assess if genistein, a biologically active isoflavone and a phytoestrogen with structure similar to that of E2, not only helps alleviate the adverse of intravesical BCG therapy but also improves its efficacy (NCT01489813; started in May 2017). In this study, either genistein supplement or placebo is given to the patients with NMI bladder tumor for 10 weeks (i.e., during BCG therapy and one-month post-therapy). Several antibodies against programmed cell death-1 (PD-1) or its ligand (PD-L1) have recently been approved by the U.S. Food and Drug Administration, and there are a number of PD-1/PD-L1 inhibitors entering clinical trials [65]. These drugs, as immune checkpoint inhibitors that attack tumor cells via enhancing the host immune response, are expected to considerably improve the prognosis of various types of malignancies, including bladder cancer. Importantly, the efficacy of PD-1/PD-L1 inhibitors is often associated with the levels of PD-L1 expression [86]. In an immunohistochemical study in MI bladder cancers, PD-L1 expression was shown to be inversely correlated with the levels of AR expression [87]. We have confirmed this inverse correlation in bladder cancer cell lines (Teramoto and Miyamoto, unpublished data). In breast cancer specimens, an inverse correlation of ER $\alpha$ status with PD-L1 mRNA expression has also been documented [88].

\section{Conclusions}

Current evidence indicates a critical role of sex hormone receptor signaling in bladder cancer progression, supporting that urothelial cancer is an endocrine-related neoplasm. However, it remains uncovered how AR and ERs function in urothelial cancer cells. Various studies have also suggested the involvement of sex hormone receptors in modulating sensitivity to conventional non-surgical therapy for bladder cancer. Specifically, activation of AR and ER signals appears to be associated with resistance to chemotherapy, radiotherapy, and BCG immunotherapy, although limited data, especially those on ER $\alpha$, are available. Accordingly, concurrent inactivation of these, using, for example, anti-AR or anti-ER agents widely used for the treatment of other pathologic conditions such as prostate and breast cancers, is anticipated to improve patient outcomes via sensitizing the efficacy of the conventional therapy, in addition to direct inhibitory effects of androgen/estrogen deprivation. Meanwhile, eventual resistance to standard hormonal therapy remains a critical issue in patients with prostate or breast cancer. Indeed, an AR variant, which is implicated in the development of castration-resistant prostate cancer, has recently been identified in bladder cancer [89]. Further investigation of AR and ERs, as well as other molecules directly or indirectly regulated by AR/ER signals, is required for determining the precise actions of androgens/estrogens in bladder cancer cells, in relation to their impact on modulating sensitivity to conventional therapy, as well as underlying molecular mechanisms for their actions.

Author Contributions: Conceptualization, H.I. and H.M.; writing-original draft preparation, H.I.; writing-review and editing, H.M. All authors have read and agreed to the published version of the manuscript.

Funding: This research received no external funding.

Institutional Review Board Statement: Not applicable.

Informed Consent Statement: Not applicable.

Data Availability Statement: Not applicable.

Conflicts of Interest: The authors declare no conflict of interest. 


\section{References}

1. Bray, F.; Ferlay, J.; Soerjomataram, I.; Siegel, R.L.; Torre, L.A.; Jemal, A. Global cancer statistics 2018: GLOBOCAN estimates of incidence and mortality worldwide for 36 cancers in 185 countries. CA Cancer J. Clin. 2018, 68, 394-424. [CrossRef]

2. Torre, L.A.; Bray, F.; Siegel, R.L.; Ferlay, J.; Lortet-Tieulent, J.; Jemal, A. Global cancer statistics, 2012. CA Cancer J. Clin. 2015, 65, 87-108. [CrossRef]

3. Chou, R.; Selph, S.; Buckley, D.I.; Fu, R.; Griffin, J.C.; Grusing, S.; Gore, J.L. Intravesical therapy for the treatment of nonmuscle invasive bladder cancer: A systematic review and meta-analysis. J. Urol. 2017, 197, 1189-1199. [CrossRef]

4. Ploussard, G.; Daneshmand, S.; Efstathiou, J.A.; Herr, H.W.; James, N.D.; Rodel, C.M.; Shariat, S.F.; Shipley, W.U.; Sternberg, C.N.; Thalmann, G.N.; et al. Critical analysis of bladder sparing with trimodal therapy in muscle-invasive bladder cancer: A systematic review. Eur. Urol. 2014, 66, 120-137. [CrossRef]

5. Lobo, N.; Mount, C.; Omar, K.; Nair, R.; Thurairaja, R.; Khan, M.S. Landmarks in the treatment of muscle-invasive bladder cancer. Nat. Rev. Urol. 2017, 14, 565-574. [CrossRef] [PubMed]

6. Lenis, A.T.; Lec, P.M.; Chamie, K.; Mshs, M.D. Bladder cancer: A review. JAMA 2020, 324, 1980-1991. [CrossRef] [PubMed]

7. Patel, V.G.; Oh, W.K.; Galsky, M.D. Treatment of muscle-invasive and advanced bladder cancer in 2020. CA Cancer J. Clin. 2020, 70, 404-423. [CrossRef]

8. Ide, H.; Miyamoto, H. The role of steroid hormone receptors in urothelial tumorigenesis. Cancers 2020, 12, 2155. [CrossRef] [PubMed]

9. Miyamoto, H.; Yang, Z.; Chen, Y.T.; Ishiguro, H.; Uemura, H.; Kubota, Y.; Nagashima, Y.; Chang, Y.J.; Hu, Y.C.; Tsai, M.Y.; et al. Promotion of bladder cancer development and progression by androgen receptor signals. J. Natl. Cancer Inst. 2007, 99, 558-568. [CrossRef] [PubMed]

10. Izumi, K.; Zheng, Y.; Hsu, J.W.; Chang, C.; Miyamoto, H. Androgen receptor signals regulate UDP-glucuronosyltransferases in the urinary bladder. Mol. Carcinog. 2013, 52, 94-102. [CrossRef]

11. Nagata, Y.; Miyamoto, H. The prognostic role of steroid hormone receptor signaling pathways in urothelial carcinoma. Transl. Cancer Res. 2020, 9, 6596-6608. [CrossRef]

12. Johnson, A.M.; O'Connell, M.J.; Messing, E.M.; Reeder, J.E. Decreased bladder cancer growth in parous mice. Urology 2008, 72, 470-473. [CrossRef] [PubMed]

13. Wolpert, B.J.; Amr, S.; Ezzat, S.; Saleh, D.; Gouda, I.; Loay, I.; Hifnawy, T.; Mikhail, N.N.; Abdel-Hamid, M.; Zhan, M.; et al. Estrogen exposure and bladder cancer risk in Egyptian women. Maruritas 2010, 67, 353-357. [CrossRef]

14. Boorjian, S.; Ugras, S.; Mongan, N.P.; Gudas, L.J.; You, X.; Tickoo, S.K.; Scherr, D.S. Androgen receptor expression is inversely correlated with pathologic tumor stage in bladder cancer. Urology 2004, 64, 383-388. [CrossRef] [PubMed]

15. Boorjian, S.A.; Heemers, H.V.; Frank, I.; Farmer, S.A.; Schmidt, L.J.; Sebo, T.J.; Tindall, D.J. Expression and significance of androgen receptor coactivators in urothelial carcinoma of the bladder. Endocr. Relat. Cancer 2009, 16, 123-137. [CrossRef] [PubMed]

16. Mir, C.; Shariat, S.F.; van der Kwast, T.H.; Ashfaq, R.; Lotan, Y.; Evans, A.; Skeldon, S.; Hanna, S.; Vajpeyi, R.; Kuk, C.; et al. Loss of androgen receptor expression is not associated with pathological stage, grade, gender or outcome in bladder cancer: A large multi-institutional study. BJU Int. 2011, 108, 24-30. [CrossRef] [PubMed]

17. Tuygun, C.; Kankaya, D.; Imamoglu, A.; Sertcelik, A.; Zengin, K.; Oktay, M.; Sertcelik, N. Sex-specific hormone receptors in urothelial carcinomas of the human urinary bladder: A comparative analysis of clinicopathological features and survival outcomes according to receptor expression. Urol. Oncol. 2011, 29, 43-51. [CrossRef]

18. Miyamoto, H.; Yao, J.L.; Chaux, A.; Zheng, Y.; Hsu, I.; Izumi, K.; Chang, C.; Messing, E.M.; Netto, G.J.; Yeh, S. Expression of androgen and oestrogen receptors and its prognostic significance in urothelial neoplasm of the urinary bladder. BJU Int. 2012, 109, 1716-1726. [CrossRef]

19. Jing, Y.; Cui, D.; Guo, W.; Jiang, J.; Jiang, B.; Lu, Y.; Zhao, W.; Wang, X.; Jiang, Q.; Han, B.; et al. Activated androgen receptor promotes bladder cancer metastasis via Slug mediated epithelial-mesenchymal transition. Cancer Lett. 2014, 348, 135-145. [CrossRef]

20. Nam, J.K.; Park, S.W.; Lee, S.D.; Chung, M.K. Prognostic value of sex-hormone receptor expression in non-muscle-invasive bladder cancer. Yonsei Med. J. 2014, 55, 1214-1221. [CrossRef]

21. Elzamy, S.; Ms, A.A.; Kandeel, W. The prognostic significance of androgen receptor and $\beta$-catenin immunohistochemical expression in urothelial carcinoma with and without detrusor muscle invasion from an Egyptian institution. Pol. J. Pathol. 2018, 69, 234-242. [CrossRef] [PubMed]

22. Tyagi, A.; Chandrasekaran, B.; Kolluru, V.; Rai, S.; Jordan, A.C.; Houda, A.; Messer, J.; Ankem, M.; Damodaran, C.; Haddad, A. Combination of androgen receptor inhibitor and cisplatin, an effective treatment strategy for urothelial carcinoma of the bladder. Urol. Oncol. 2019, 37, 492-502. [CrossRef]

23. Yonekura, S.; Terauchi, F.; Hoshi, K.; Yamaguchi, T.; Kawai, S. Androgen receptor predicts first and multiple recurrences in non-muscle invasive urothelial carcinoma of the bladder. Pathol. Oncol. Res. 2019, 25, 987-994. [CrossRef] [PubMed]

24. Toren, P.; Brisson, H.; Simonyan, D.; Hovington, H.; Lacombe, L.; Bergeron, A.; Fradet, Y. Androgen receptor and immune cell PD-L1 expression in bladder tumors predicts disease recurrence and survival. World J. Urol. 2020. [CrossRef]

25. Ide, H.; Inoue, S.; Miyamoto, H. Histopathological and prognostic significance of the expression of sex hormone receptors in bladder cancer: A meta-analysis of immunohistochemical studies. PLoS ONE 2017, 12, 0174746. [CrossRef] [PubMed] 
26. Wu, J.T.; Han, B.M.; Yu, S.Q.; Wang, H.P.; Xia, S.J. Androgen receptor is a potential therapeutic target for bladder cancer. Urology 2010, 75, 820-827. [CrossRef] [PubMed]

27. Zheng, Y.; Izumi, K.; Yao, J.L.; Miyamoto, H. Dihydrotestosterone upregulates the expression of epidermal growth factor receptor and ERBB2 in androgen receptor-positive bladder cancer cells. Endocr. Relat. Cancer 2011, 18, 451-464. [CrossRef]

28. Izumi, K.; Zheng, Y.; Li, Y.; Zaengle, J.; Miyamoto, H. Epidermal growth factor induces bladder cancer cell proliferation through activation of the androgen receptor. Int. J. Oncol. 2012, 41, 1587-1592. [CrossRef]

29. Overdevest, J.B.; Knubel, K.H.; Duex, J.E.; Thomas, S.; Nitz, M.D.; Harding, M.A.; Smith, S.C.; Frierson, H.F.; Conaway, M.; Theodorescu, D. CD24 expression is important in male urothelial tumorigenesis and metastasis in mice and is androgen regulated. Proc. Natl. Acad. Sci. USA 2012, 109, 3588-3596. [CrossRef]

30. Shiota, M.; Takeuchi, A.; Yokomizo, A.; Kashiwagi, E.; Tatsugami, K.; Kuroiwa, K.; Naito, S. Androgen receptor signaling regulates cell growth and vulnerability to doxorubicin in bladder cancer. J. Urol. 2012, 188, 276-286. [CrossRef]

31. Kawahara, T.; Ide, H.; Kashiwagi, E.; El-Shishtawy, K.A.; Li, Y.; Reis, L.O.; Zheng, Y.; Miyamoto, H. Enzalutamide inhibits androgen receptor-positive bladder cancer cell growth. Urol. Oncol. 2016, 34, 15-23. [CrossRef] [PubMed]

32. Ide, H.; Mizushima, T.; Jiang, G.; Goto, T.; Nagata, Y.; Teramoto, Y.; Inoue, S.; Li, Y.; Kashiwagi, E.; Baras, A.S.; et al. FOXO1 as a tumor suppressor inactivated via AR/ER $\beta$ signals in urothelial cells. Endocr. Relat. Cancer 2020, 27, 231-244. [CrossRef]

33. Ding, G.; Yu, S.; Cheng, S.; Li, G.; Yu, Y. Androgen receptor (AR) promotes male bladder cancer cell proliferation and migration via regulating CD24 and VEGF. Am. J. Transl. Res. 2016, 8, 578-587. [PubMed]

34. Johnson, A.M.; O'Connell, M.J.; Miyamoto, H.; Huang, J.; Yao, J.L.; Messing, E.M.; Reeder, J.E. Androgenic dependence of exophytic tumor growth in a transgenic mouse model of bladder cancer: A role for thrombospondin-1. BMC Urol. 2008, 8, 7. [CrossRef]

35. Inoue, S.; Mizushima, T.; Ide, H.; Jiang, G.; Goto, T.; Nagata, Y.; Netto, G.J.; Miyamoto, H. ATF2 promotes urothelial cancer outgrowth via cooperation with androgen receptor signaling. Endocr. Connect. 2018, 7, 1397-1408. [CrossRef] [PubMed]

36. Li, Y.; Zheng, Y.; Izumi, K.; Ishiguro, H.; Ye, B.; Li, F.; Miyamoto, H. Androgen activates $\beta$-catenin signaling in bladder cancer cells. Endocr. Relat. Cancer 2013, 20, 293-304. [CrossRef]

37. Kawahara, T.; Shareef, H.K.; Aljarah, A.K.; Ide, H.; Li, Y.; Kashiwagi, E.; Netto, G.J.; Zheng, Y.; Miyamoto, H. ELK1 is up-regulated by androgen in bladder cancer cells and promotes tumor progression. Oncotarget 2015, 30, 29860-29876. [CrossRef] [PubMed]

38. Chen, F.; Langenstroer, P.; Zhang, G.; Iwamoto, Y.; See, W. Androgen dependent regulation of bacillus Calmette-Guérin induced interleukin-6 expression in human transitional carcinoma cell lines. J. Urol. 2003, 170, 2009-2013. [CrossRef]

39. Inoue, S.; Ide, H.; Mizushima, T.; Jiang, G.; Netto, G.J.; Gotoh, M.; Miyamoto, H. Nuclear factor-kB promotes urothelial tumorigenesis and cancer progression via cooperation with androgen receptor signaling. Mol. Cancer Ther. 2018, 17, 1303-1314. [CrossRef] [PubMed]

40. Zhu, B.T.; Han, G.Z.; Shim, J.Y.; Wen, Y.; Jiang, X.R. Quantitative structure-activity relationship of various endogenous estrogen metabolites for human estrogen receptor $\alpha$ and $\beta$ subtypes: Insights into the structural determinants favoring a differential subtype binding. Endocrinology 2006, 147, 4132-4150. [CrossRef] [PubMed]

41. Imai, Y.; Noda, S.; Matsuyama, C.; Shimizu, A.; Kamai, T. Sex steroid hormone receptors in bladder cancer: Usefulness in differential diagnosis and implications in histogenesis of bladder cancer. Urol. Oncol. 2019, 37, 353. [CrossRef]

42. Bernardo, C.; Santos, J.; Costa, C.; Tavares, A.; Amaro, T.; Marques, I.; Gouveia, M.J.; Felix, V.; Afreixo, V.; Brindley, P.J.; et al. Estrogen receptors in urogenital schistosomiasis and bladder cancer: Estrogen receptor alpha-mediated cell proliferation. In Urologic Oncology: Seminars and Original Investigations; Elesvier: Amsterdam, The Netherlands, 2020; Volume 38, pp. 738.e23-738.e35. [CrossRef] [PubMed]

43. Croft, P.R.; Lathrop, S.L.; Feddersen, R.M.; Joste, N.E. Estrogen receptor expression in papillary urothelial carcinoma of the bladder and ovarian transitional cell carcinoma. Arch. Pathol. Lab. Med. 2005, 129, 194-199. [CrossRef]

44. Shen, S.S.; Smith, C.L.; Hsieh, J.T.; Yu, J.; Kim, I.Y.; Jian, W.; Sonpavde, G.; Ayala, G.E.; Younes, M.; Lerner, S.P. Expression of estrogen receptors- $\alpha$ and $-\beta$ in bladder cancer cell lines and human bladder tumor tissue. Cancer 2006, 106, 2610-2616. [CrossRef] [PubMed]

45. Kontos, S.; Kominea, A.; Melachrinou, M.; Balampani, E.; Sotiropoulou-Bonikou, G. Inverse expression of estrogen receptor- $\beta$ and nuclear factor- $\mathrm{kB}$ in urinary bladder carcinogenesis. Int. J. Urol. 2010, 17, 801-809. [CrossRef]

46. Tan, W.; Boorjian, S.; Advani, P.; Farmer, S.; Lohse, C.; Cheville, J.; Kwon, E.; Leibovich, B. The Estrogen Pathway: Estrogen receptor- $\alpha$, progesterone receptor, and estrogen receptor- $\beta$ expression in radical cystectomy urothelial cell carcinoma specimens. Clin. Genitourin. Cancer 2015, 13, 476-484. [CrossRef] [PubMed]

47. Nguyen, D.P.; O’Malley, P.; Al Hussein Al Awamlh, B.; Furrer, M.A.; Mongan, N.P.; Robinson, B.D.; Wang, G.J.; Scherr, D.S. Association of aromatase with bladder cancer stage and long-term survival: New insights into the hormonal paradigm in bladder cancer. Clin. Genitourin. Cancer 2017, 15, 256-262. [CrossRef]

48. Andersson, S.; Sundberg, M.; Pristovsek, N.; Ibrahim, A.; Jonsson, P.; Katona, B.; Clausson, C.M.; Zieba, A.; Ramstrom, M.; Soderberg, O.; et al. Insufficient antibody validation challenges oestrogen receptor beta research. Nat. Commun. 2017, 8, 15840. [CrossRef] [PubMed]

49. Nelson, A.W.; Groen, A.J.; Miller, J.L.; Warren, A.Y.; Holmes, K.A.; Tarulli, G.A.; Tilley, W.D.; Katzenellenbogen, B.S.; Hawse, J.R.; Gnanapragasam, V.J.; et al. Comprehensive assessment of estrogen receptor beta antibodies in cancer cell line models and tissue reveals critical limitations in reagent specificity. Mol. Cell. Endocrinol. 2017, 440, 138-150. [CrossRef] 
50. Teng, J.; Wang, Z.Y.; Jarrard, D.F.; Bjorling, D.E. Roles of estrogen receptor $\alpha$ and $\beta$ in modulating urothelial cell proliferation. Endocr. Relat. Cancer 2008, 15, 351-364. [CrossRef]

51. Hoffman, K.L.; Lerner, S.P.; Smith, C.L. Raloxifene inhibits growth of RT4 urothelial carcinoma cells via estrogen receptordependent induction of apoptosis and inhibition of proliferation. Horm. Cancer 2013, 4, 24-35. [CrossRef] [PubMed]

52. Kim, H.T.; Kim, B.C.; Kim, I.Y.; Mamura, M.; Seong, D.H.; Jang, J.J.; Kim, S.J. Raloxifene, a mixed estrogen agonist/antagonist, induces apoptosis through cleavage of BAD in TSU-PR1 human cancer cells. J. Biol. Chem. 2002, 277, 32510-32515. [CrossRef] [PubMed]

53. Sonpavde, G.; Okuno, N.; Weiss, H.; Yu, J.; Shen, S.S.; Younes, M.; Jian, W.; Lerner, S.P.; Smith, C.L. Efficacy of selective estrogen receptor modulators in nude mice bearing human transitional cell carcinoma. Urology 2007, 69, 1221-1226. [CrossRef]

54. Hsu, I.; Chuang, K.L.; Slavin, S.; Da, J.; Lim, W.X.; Pang, S.T.; O’Brien, J.H.; Yeh, S. Suppression of ER $\beta$ signaling via ER $\beta$ knockout or antagonist protects against bladder cancer development. Carcinogenesis 2014, 35, 651-661. [CrossRef]

55. Huang, C.P.; Chen, J.; Chen, C.C.; Liu, G.; Zhang, Y.; Messing, E.; Yeh, S.; Chang, C. ASC-J9 ${ }^{\circledR}$ increases the bladder cancer chemotherapy efficacy via altering the androgen receptor (AR) and NF-kB survival signals. J. Exp. Clin. Cancer Res. 2019, 38,275 [CrossRef] [PubMed]

56. Hsu, I.; Yeh, C.R.; Slavin, S.; Miyamoto, H.; Netto, G.J.; Tsai, Y.C.; Muyan, M.; Wu, X.R.; Messing, E.M.; Guancial, E.A.; et al. Estrogen receptor alpha prevents bladder cancer via INPP4B inhibited akt pathway in vitro and in vivo. Oncotarget 2014, 5, 7917-7935. [CrossRef]

57. Izumi, K.; Li, Y.; Ishiguro, H.; Zheng, Y.; Yao, J.L.; Netto, G.J.; Miyamoto, H. Expression of UDP-glucuronosyltransferase 1A in bladder cancer: Association with prognosis and regulation by estrogen. Mol. Carcinog. 2014, 53, 314-324. [CrossRef] [PubMed]

58. Han, B.; Cui, D.; Jing, Y.; Hong, Y.; Xia, S. Estrogen receptor $\beta(E R \beta)$ is a novel prognostic marker of recurrence survival in non-muscle-invasive bladder cancer potentially by inhibiting cadherin switch. World J. Urol. 2012, 30, 861-867. [CrossRef]

59. George, S.K.; Tovar-Sepulveda, V.; Shen, S.S.; Jian, W.; Zhang, Y.; Hilsenbeck, S.G.; Lerner, S.P.; Smith, C.L. Chemoprevention of BBN-induced bladder carcinogenesis by the selective estrogen receptor modulator tamoxifen. Transl. Oncol. 2013, 6, 244-255. [CrossRef]

60. Ding, M.; Liu, Y.; Li, J.; Yao, L.; Liao, X.; Xie, H.; Yang, K.; Zhou, Q.; Liu, Y.; Huang, W.; et al. Oestrogen promotes tumorigenesis of bladder cancer by inducing the enhancer RNA-eGREB1. J. Cell. Mol. Med. 2018, 22, 5919-5927. [CrossRef]

61. Ding, M.; Zhan, H.; Liao, X.; Li, A.; Zhong, Y.; Gao, Q.; Liu, Y.; Huang, W.; Cai, Z. Enhancer RNA - P2RY2e induced by estrogen promotes malignant behaviors of bladder cancer. Int. J. Biol. Sci. 2018, 14, 1268-1276. [CrossRef]

62. Ou, Z.; Wang, Y.; Chen, J.; Tao, L.; Zuo, L.; Sahasrabudhe, D.; Joseph, J.; Wang, L.; Yeh, S. Estrogen receptor $\beta$ promotes bladder cancer growth and invasion via alteration of miR-92a/DAB2IP signals. Exp. Mol. Med. 2018, 50, 1-11. [CrossRef] [PubMed]

63. Ge, Q.; Lu, M.; Ju, L.; Qian, K.; Wang, G.; Wu, C.L.; Liu, X.; Xiao, Y.; Wang, X. miR-4324-RACGAP1-STAT3-ESR1 feedback loop inhibits proliferation and metastasis of bladder cancer. Int. J. Cancer 2019, 144, 3043-3055. [CrossRef]

64. Wu, L.; Zhang, M.; Qi, L.; Zu, X.; Li, Y.; Liu, L.; Chen, M.; Li, Y.; He, W.; Hu, X.; et al. ER $\alpha$-mediated alterations in circ_0023642 and miR-490-5p signaling suppress bladder cancer invasion. Cell Death Dis. 2019, 10, 635. [CrossRef] [PubMed]

65. Goto, T.; Miyamoto, H. Why has the prognosis for muscle-invasive bladder cancer not significantly improved after decades of therapeutic advancements? Expert Rev. Anticancer Ther. 2020, 20, 229-231. [CrossRef]

66. Pu, Y.S.; Hsieh, T.S.; Tsai, T.C.; Cheng, A.L.; Hsieh, C.Y.; Su, I.J.; Lai, M.K. Tamoxifen enhances the chemosensitivity of bladder carcinoma cells. J. Urol. 1995, 154, 601-605. [CrossRef]

67. Pu, Y.S.; Hsieh, T.S.; Cheng, A.L.; Tseng, N.F.; Su, I.J.; Hsieh, C.Y.; Lai, M.K.; Tsai, T.C. Combined cytotoxic effects of tamoxifen and chemotherapeutic agents on bladder cancer cells: A potential use in intravesical chemotherapy. Br. J. Urol. 1996, 77, 76-85. [CrossRef]

68. Kawahara, T.; Ide, H.; Kashiwagi, E.; Patterson, J.D.; Inoue, S.; Shareef, H.K.; Aljarah, A.K.; Zheng, Y.; Baras, A.S.; Miyamoto, H. Silodosin inhibits the growth of bladder cancer cells and enhances the cytotoxic activity of cisplatin via ELK1 inactivation. Am. J. Cancer Res. 2015, 5, 2959-2968. [PubMed]

69. Shang, Z.; Li, Y.; Zhang, M.; Tian, J.; Han, R.; Shyr, C.R.; Messing, E.; Yeh, S.; Niu, Y.; Chang, C. Antiandrogen therapy with hydroxyflutamide or androgen receptor degradation enhancer ASC-J9 enhances BCG Efficacy to better suppress bladder cancer progression. Mol. Cancer Ther. 2015, 14, 2586-2594. [CrossRef]

70. Takeuchi, H.; Mmeje, C.O.; Jinesh, G.G.; Taoka, R.; Kamat, A.M. Sequential gemcitabine and tamoxifen treatment enhances apoptosis and blocks transformation in bladder cancer cells. Oncol. Rep. 2015, 34, 2738-2744. [CrossRef] [PubMed]

71. Kashiwagi, E.; Ide, H.; Inoue, S.; Kawahara, T.; Zheng, Y.; Reis, L.O.; Baras, A.S.; Miyamoto, H. Androgen receptor activity modulates responses to cisplatin treatment in bladder cancer. Oncotarget 2016, 7, 49169-49179. [CrossRef] [PubMed]

72. Kameyama, K.; Horie, K.; Mizutani, K.; Kato, T.; Fujita, Y.; Kawakami, K.; Kojima, T.; Miyazaki, T.; Deguchi, T.; Ito, M. Enzalutamide inhibits proliferation of gemcitabine-resistant bladder cancer cells with increased androgen receptor expression. Int. J. Oncol. 2017, 50, 75-84. [CrossRef] [PubMed]

73. Ide, H.; Inoue, S.; Mizushima, T.; Jiang, G.; Chuang, K.H.; Oya, M.; Miyamoto, H. Androgen receptor signaling reduces radiosensitivity in bladder cancer. Mol. Cancer Ther. 2018, 17, 1566-1574. [CrossRef] [PubMed]

74. Long, X.; Xiong, W.; Zeng, X.; Qi, L.; Cai, Y.; Mo, M.; Jiang, H.; Zhu, B.; Chen, Z.; Li, Y. Cancer-associated fibroblasts promote cisplatin resistance in bladder cancer cells by increasing IGF-1/ERß/Bcl-2 signalling. Cell Death Dis. 2019, 10, 375. [CrossRef] 
75. Sekino, Y.; Sakamoto, N.; Ishikawa, A.; Honma, R.; Shigematsu, Y.; Hayashi, T.; Sentani, K.; Oue, N.; Teishima, J.; Matsubara, A.; et al. Transcribed ultraconserved region Uc.63+ promotes resistance to cisplatin through regulation of androgen receptor signaling in bladder cancer. Oncol. Rep. 2019, 41, 3111-3118. [CrossRef]

76. Goto, T.; Kashiwagi, E.; Jiang, G.; Nagata, Y.; Teramoto, Y.; Baras, A.S.; Yamashita, S.; Ito, A.; Arai, Y.; Miyamoto, H. strogen receptor- $\beta$ signaling induces cisplatin resistance in bladder cancer. Am. J. Cancer Res. 2020, 10, 2523-2534.

77. Ide, H.; Goto, T.; Teramoto, Y.; Mizushima, T.; Jiang, G.; Nagata, Y.; Inoue, S.; Baras, A.S.; Kashiwagi, E.; Miyamoto, H. FOXO1 inactivation induces cisplatin resistance in bladder cancer. Cancer Sci. 2020, 111, 3397-3400. [CrossRef]

78. Mizushima, T.; Jiang, G.; Kawahara, T.; Li, P.; Han, B.; Inoue, S.; Ide, H.; Kato, I.; Jalalizadeh, M.; Miyagi, E.; et al. Androgen receptor signaling reduces the efficacy of bacillus Calmette-Guérin therapy for bladder cancer via modulating Rab27b-induced exocytosis. Mol. Cancer Ther. 2020, 19, 1930-1942. [CrossRef]

79. Jiang, G.; Teramoto, Y.; Goto, T.; Mizushima, T.; Inoue, S.; Ide, H.; Nagata, Y.; Kashiwagi, E.; Baras, A.S.; Netto, G.J.; et al. Identification of BXDC2 as a key downstream effector of the androgen receptor in modulating cisplatin sensitivity in bladder cancer. Cancers 2021, 13, 975. [CrossRef]

80. Lee, K.H.; Kim, B.C.; Jeong, S.H.; Jeong, C.W.; Ku, J.H.; Kim, H.H.; Kwak, C. Histone demethylase KDM7A regulates androgen receptor activity, and its chemical inhibitor TC-E 5002 overcomes cisplatin-resistance in bladder cancer cells. Int. J. Mol. Sci. 2020, 21, 5658. [CrossRef]

81. Hsu, C.H.; Chen, J.; Wu, C.Y.; Cheng, A.L.; Pu, Y.S. Combination chemotherapy of cisplatin, methotrexate, vinblastine, and high-dose tamoxifen for transitional cell carcinoma. Anticancer Res. 2001, 21, 711-715. [PubMed]

82. Wettstein, M.S.; Rooprai, J.K.; Pazhepurackel, C.; Wallis, C.J.D.; Klaassen, Z.; Uleryk, E.M.; Hermanns, T.; Fleshner, N.E.; Zlotta, A.R.; Kulkarni, G.S. Systematic review and meta-analysis on trimodal therapy versus radical cystectomy for muscle-invasive bladder cancer: Does the current quality of evidence justify definitive conclusions? PLoS ONE 2019, 14, 0216255. [CrossRef]

83. Boorjian, S.A.; Zhu, F.; Herr, H.W. The effect of gender on response to bacillus Calmette-Guérin therapy for patients with non-muscle-invasive urothelial carcinoma of the bladder. BJU Int. 2010, 106, 357-361. [CrossRef]

84. Uhlig, A.; Strauss, A.; Seif Amir Hosseini, A.; Lotz, J.; Trojan, L.; Schmid, M.; Uhlig, J. Gender-specific differences in recurrence of non-muscle-invasive bladder cancer: A systematic review and meta-analysis. Eur. Urol. Focus 2018, 4, 924-936. [CrossRef]

85. Shang, Z.; Li, Y.; Hsu, I.; Zhang, M.; Tian, J.; Wen, S.; Han, R.; Messing, E.M.; Chang, C.; Niu, Y.; et al. Targeting estrogen/estrogen receptor alpha enhances bacillus Calmette-Guérin efficacy in bladder cancer. Oncotarget 2016, 7, 27325-27335. [CrossRef]

86. Sun, L.; Zhang, L.; Yu, J.; Zhang, Y.; Pang, X.; Ma, C.; Shen, M.; Ruan, S.; Wasan, H.S.; Qiu, S. Clinical efficacy and safety of anti-PD-1/PD-L1 inhibitors for the treatment of advanced or metastatic cancer: A systematic review and meta-analysis. Sci. Rep. 2020, 10, 2083. [CrossRef]

87. Necchi, A.; Lo Vullo, S.; Giannatempo, P.; Raggi, D.; Perrone, F.; Nicolai, N.; Catanzaro, M.; Biasoni, D.; Torelli, T.; Piva, L.; et al. Association of androgen receptor expression on tumor cells and PD-L1 expression in muscle-invasive and metastatic urothelial carcinoma: Insights for clinical research. Clin. Genitourin. Cancer 2018, 16, 403-410. [CrossRef] [PubMed]

88. Zerdes, I.; Sifakis, E.G.; Matikas, A.; Chretien, S.; Tobin, N.P.; Hartman, J.; Rassidakis, G.Z.; Bergh, J.; Foukakis, T. Programmed death-ligand 1 gene expression is a prognostic marker in early breast cancer and provides additional prognostic value to 21 -gene and 70-gene signatures in estrogen receptor-positive disease. Mol. Oncol. 2020, 14, 951-963. [CrossRef] [PubMed]

89. Katleba, K.; Lombard, A.P.; Tsamouri, M.M.; Baek, H.B.; Nishida, K.S.; Libertini, S.J.; Platero, A.J.; Ma, A.H.; Pan, C.X.; Ghosh, P.M.; et al. Depletion of androgen receptor low molecular weight isoform reduces bladder tumor cell viability and induces apoptosis. Cancer Lett. 2021, 504, 49-57. [CrossRef] [PubMed] 